\title{
Identification and Analysis of Society Opinion about Read Write Arithmetic in Early Chilhood Education
}

\author{
${ }^{\text {aI }}$ Made Tegeh, ${ }^{\mathrm{b}}$ Luh Putu Putrini Mahadewi, ${ }^{\mathrm{c} I}$ Nyoman Jampel \\ anniversitas Pendidikan Ganesha, Jl. Udayana 11, Singaraja, Indonesia \\ bUniversitas Pendidikan Ganesha, Jl. Udayana 11, Singaraja, Indonesia \\ 'Universitas Pendidikan Ganesha, Jl. Udayana 11, Singaraja, Indonesia \\ Corresponding e-mail: imadetegehderana@yahoo.com
}

\begin{abstract}
This research aimed at describing: (1) society opinion about implementation of read write arithmetic programme in early chilhood education, (2) the way of read write arithmetic implementation, (3) incorectly implemetation of read write arithmetic programme in early chilhood education, (4) the effort for preventing and solution implemetation of read write arithmetic programme in early chilhood education, and (5) the society opinion about implementation of selection test for new student in elementary school. This was a survey research. Population consisted of society at the Buleleng district, regency of Buleleng. This sample consisted of 48 respondent chosen through by cluster random sampling. The research instruments were quesionare, inventory, and interview. The data analysis was qualitative descriptive. The result showed that: (1) $58,33 \%$ society agree to implementation of read write arithmetic programme in early chilhood education, (2) there were some ways of read write arithmetic implementation, (3) there were some incorectly implemetation of read write arithmetic programme in early chilhood education, (4) there were some efforts for preventing and solution implemetation of read write arithmetic programme in early chilhood education, and (5) $43,75 \%$ society agree to implementation of selection test for new student in elementary school.
\end{abstract}

Keywords - early childhood, education, read, write, arithmetic

\section{Introduction}

Parents' ambitions to make their children smarter tend to encourage education provider to organize education without clear planning. Especially parents who are in established economic status, dare to sacrifice paying education managers including teachers with high cost. This condition occurs in Early Childhood Education (PAUD). The results of monitoring of several institutions of PAUD education providers in Bali heard that parents dare to spend high funds to pay the cost of education of their children to be quick smart in some subjects that are requested by parents. The subjects in question include, reading, writing, arithmetic, even up to English subjects. Parents' expectations, at least their children are smart in these four subjects. Fulfill this expectation schools and foundations no longer think of the problem of teacher qualifications that will teach at this level, it is important that teachers who will teach have competencies in the subjects taught. Indeed, professional competence is important for a teacher, but other competencies such as pedagogical, personality, and social competencies are equally important. Focus on professional competence, then teachers who are recruited as teaching staff are no longer graduates of educational staff, but graduates of one university or noneducated university. Ironically again, there were many graduates of educational staff who were prepared as educators in early childhood, no longer able to fill the formation in the institution, because less proficient in English. Finally, the teacher is a non-educated university graduate and does not dismiss is a graduate of High School. The latter was recruited for being a smart English speaker.
In terms of understanding the development of children, the recruitment conditions of prospective teachers like this certainly does not provide a sense of comfort for children in the education process. This will certainly occur because their understanding of early childhood development is not holistic. Comments Sukirman (2014: 5) an expert on Early Childhood Education in his paper on Pedagogical Reviews Learning literacy in PAUD would be very appropriate. He said, "schooling is a long term, so do not be burdened with the contents of the curriculum that has not been the time that will create a sense of hatred of school institutions. ... because, if the child is learning in an unsafe or uncomfortable condition, his or her brain stem will react by resisting or avoiding.

The question is, does literacy reading should or should not be taught to children in PAUD programs? Gearge S. Morrison's answer, (2012: 262) is, "may", provided that it is done by a competent teacher in a manner consistent with the child's developmental stage. To achieve the level of readiness, many requirements must be met. In addition to biological factors, many more readiness indicators must be met. For example, the child is said to be ready to read, if the child has understood phonemes, phonemics, phonology, and writing. The child is said to be ready to write if his fingers are strong enough to hold the stationery for a period of time, his fine motor movement is capable of directing the scratches, and his emotions are under control to do this work. While said to be ready to count if the child has started to have an understanding of the concept of numbers, it must also be done by using concrete objects. This readiness generally appears naturally around the age of 5, 6, or 7 years. It depends on genetic factors and environmental factors on literacy programs. 
Literacy is traditionally interpreted as the ability to use language to read and write (Warsihna, 2016).

There are children who are able to read and write fluently, as long as done naturally in accordance with the stages of child development, then legitimate. But if the educator has not been able to do it right, it is better to do literacy teaching done in the early classes. Sukiman (2014: 4) argues that we should not be done is "coercive" or "patterns of drilling" in order to achieve the competence of literacy reading children, by ignoring the best interests of children. Referring to the Regulation of the Minister of National Education No. 58 of 2009 on the standards of early childhood language development in the subkeys for groups of children aged 5-6 years only includes: (1) mentioning the symbols of known letters, (2) recognizing the sound of the initial letter of the name of the object- (3) mentioning groups of images that have the same initial sounds / letters, (4) understanding the relationship between sound and letter form, and (5) writing their own names. The regulation explicitly says that language skills are a process. How the language proceeds can be known when someone is listening, speaking, reading, and writing (Musfiroh, 2009).

Understanding the community including the current school community about the provision of literacy programs in PAUD counting program is very diverse. Some agree and some disagree with the various arguments each. Information from the supervisors and teachers of Early Childhood Education when the Undiksha Research Center conducted Focus Group Discussion (FGD) with elementary and kindergarten supervisors, PAUD teachers, and non-formal education staff within the District Education Office of Buleleng District, Some elementary schools that require mastery of reading, writing and arithmetic/numeracy in the acceptance of new students of first grade. However, there are also primary schools that do not require such requirement. Because if the first requirement is treated there is a possibility that most of the prospective students of primary school, especially those in rural areas who do not have early childhood experience or who have early childhood experience but who do not master reading, writing and arithmetic skills, are certainly not acceptable as elementary school students. This condition would certainly be contrary to the government's mandatory learning program. Therefore, in this opportunity try to do research about attitudes or opinions of the community to the implementation of the reading, writing, and arithmetic program in Early Childhood Education program.

\section{Research Methods}

This study included survey research. According to Daniel (2003: 44) the survey is "a critical observation or inquiry to get a good explanation of a particular issue within a particular area or location, or an extensively studied study to obtain the necessary information".

Singarimbun (1989) states that survey research can be used for the purposes of (1) explorative, (2) descriptive, (3) explanatory or confirmatory, (4) evaluation, (5) prediction or predicting certain events of the day Future operations, (6) operational research, and (7) development of social indicators. In this survey research, the purpose of research is emphasized on the assessment and descriptive. Penjajagan intended to explore the various information needed with respect to the attitude of the community to literacy reading in PAUD. Descriptive is meant for careful measurement of certain social phenomena. Researchers develop concepts and collect facts, but do not test hypotheses.

The population of this study is the community in Buleleng District, Buleleng Regency, Bali Province. Given the wide range of population and limited time and energy available, sampling is taken. The sample of research in this study selected by cluster random sampling. The sample distribution includes four components of society. First, education practitioners such as, 6 primary school teachers, 6 PAUD teachers, 6 headmasters, 6 PAUD heads, 2 Association of Kindergarten Teacher (IGTKI) heads. Respondents cover areas in cities, suburbs, and villages. Secondly, government officials as policy makers in the District Education Office Buleleng especially in PAUD, such as, 1 head of Education Implementation Unit and 1 head of Formal and Non Formal Education of Buleleng Regency, and 2 supervisors of kindergartens and supervisors of elementary school. Third, education experts consisting of 3 educational experts, and 3 psychologists (psychologists) in the Undiksha. Fourth, this research also use parent/guardian of student as the respondent that is 6 parent of elementary school student, and 6 parent of kindergarten student. The total sample is 48 people.

The data required in this study is the primary data obtained from the respondents. In survey research method or survey analysis, research instruments commonly used there are two types, namely questionnaires and interviews (Danim, 2007). Singarimbun (1989) suggests that survey research is a study that takes samples from one population and uses a questionnaire as a primary data collection tool.

Data collection methods used were inventory, questionnaire, and interview. Inventory method is used to obtain information about public attitudes toward literacy programs in PAUD. The questionnaire method is used to collect data on (1) how to implement calistung program on Early Childhood Education; (2) errors occurring in the field regarding the application of literacy programs in Early Childhood Education; (3) efforts that can be made to prevent and overcome errors that occur in the field with regard to the implementation of literacy programs in Early Childhood Education; and (4) public 
opinion about the implementation of the test in admission of new students in primary school.

To anticipate the possibility of obtaining less valid data due to the use of inventory and questionnaires, the data collection is supplemented by interviewing techniques. Based on the three data collection techniques, the data collection instruments used are inventory sheets in the form of attitude scales, questionnaire sheets, and interview guidelines.

The data collected in this research is qualitative data. Therefore, data processing using qualitative descriptive analysis. Qualitative descriptive analysis is used to give meaning to the description of the data about the content / content, the logic of inference, and the process. Data obtained through inventory sheets are grouped and given meaning to be drawn conclusions. Data obtained through the inventory sheet in the form of attitude scale and data obtained through the questionnaire sheet ditriangulasi with data obtained through interview method to obtain valid data. In other words, data obtained through inventory and questionnaires are checked and matched with data obtained through interviews. The data collected in this research is qualitative data. Therefore, data processing using qualitative descriptive analysis. Qualitative descriptive analysis is used to give meaning to the description of the data about the content / content, the logic of inference, and the process. Data obtained through inventory sheets are grouped and given meaning to be drawn conclusions. Data obtained through the inventory sheet in the form of attitude scale and data obtained through the questionnaire sheet ditriangulasi with data obtained through interview method to obtain valid data. In other words, data obtained through inventory and questionnaires are checked and matched with data obtained through interviews.

\section{Discussion of Results}

Discussion of research results is adjusted to the presentation of research results. The results of the study relating to the five problem formulations were discussed per group, which included respondents group of government officials, primary school groups, expert groups, and kindergarten groups.

Of the six respondents from the respondent group of government officials, it is known that $33.33 \%$ agreed with the implementation of literacy reading program in early childhood with the notes of the implementation of literacy program that is adjusted to the origin and characteristics of the early childhood (AUD) and conducted with interesting teaching methods (learning Playing) will contribute positively to the growth and development of the AUD. As many as $66.67 \%$ of respondents did not agree with the implementation of literacy reading program in early childhood for the following reasons: (a) Early childhood is the beginning of the child to know the school world and the surrounding environment, so it will be a tough task if AUD taught literacy, (B) PAUD still focuses on stimulating sensory, motor, and cognitive nerves, (c) most PAUD institutions implement literacy programs based on the demands of parents who expect their children to be admitted to a favorite Primary School and as a result the child's right to Play will be captured and a deep fear appears in children who are not good at literacy.

Of the six primary school principals who became respondents, it is known that 4 respondents agreed with the implementation of literacy reading program in PAUD with rational: (a) planting basic concept of literacy count is important before students enter primary school education level, (b) Uruf and numbers are the symbols around the child, so children need to recognize the symbols since early (early childhood). But there are also two respondents who disagree if the literacy reading program is applied in early childhood considering the AUD is not ready burdened with literacy and child counting material is still dominated by the desire to play. In addition, the implementation of literacy programs often cause counterculture and boredom in children.

Of the six primary class teachers who became respondents, it was found out that 5 respondents agreed with the implementation of literacy programs at PAUD institutions, for the following reasons: (a) enactment of the 2013 curriculum in primary school requires the AUD child to know the literacy program Count even though it is still an introduction, (b) literacy knowledge obtained in early childhood will make it easier for learners to understand the lessons given in elementary school. However, one respondent expressed disagreement with the implementation of literacy reading program in early childhood because the AUD is not ready to receive the literacy materials (not ready cognitively), so the literacy program is more suitable to be applied simultaneously in grade 1 elementary school.

Of the six parents of grade 1 primary school students who responded, four respondents agreed with the implementation of literacy reading program in early childhood because children at this age have a good absorption of new things, but educators are expected to teach Reading and writing materials with an interesting method (learn while playing), so unwittingly, learners have studied literacy reading. On the other hand, there are two parents who do not agree with the implementation of literacy reading program in early childhood because that should be emphasized on the AUD is the planting of character and noble character is not knowledge of letters and numbers.

Of the six parents of grade 1 primary school students who responded, four respondents agreed with the implementation of literacy reading program in early childhood because children at this age have a good absorption of new things, but educators are expected to teach Reading and writing materials with an interesting 
method (learn while playing), so unwittingly, learners have studied literacy reading. On the other hand, there are two parents who do not agree with the implementation of literacy reading program in early childhood because that should be emphasized on the AUD is the planting of character and noble character is not knowledge of letters and numbers.

However, the realization of this program should pay attention to the following matters: (a) the characteristics and stages of AUD development that are still dominated by the interest to play; (b) the teaching methods employed by the educator must be innovative, varied and interesting, so that boredom and distress Children can be minimized, but on the other hand can increase interest in children's learning, (c) always attempted to establish intensive communication and coordination with parents to jointly monitor the development of AUD. With the solid preparation and implementation of educators and parents, the literacy program will contribute positively to the growth and development of children.

From the analysis, it can be concluded that $50 \%$ of respondents do not agree with the implementation of literacy reading program in PAUD institutions because: (a) reality in the field shows there are still many PAUD institutions that have not been able to provide literacy reading program in accordance with the characteristics of PAUD students, (B) AUD does not have complete readiness when burdened with academic load, and it is feared that students will quickly experience saturation while in elementary school.

As many as $50 \%$ of respondents agreed with the implementation of literacy reading program in early childhood, because cognitively, early childhood has the ability to understand the symbols that exist, so if applied literacy programs calculate with the right method then the child will be able to understand the letter and numbers well. However, for the implementation of literacy programs to run well in the field, the educators should understand the stages of child development and trained to apply relevant methods during the implementation of literacy program. In addition, it is necessary to conduct intensive monitoring from experts / assessors and related government so that the obstacles that arise during the implementation of literacy program can be addressed immediately addressed.

Of the six respondents of Head of Kindergarten, it is known that four respondents expressed disagreement with the implementation of literacy reading program in early childhood, with some rational: (a) the early age is the time to play children, know the surrounding environment, if the program is implemented then The freedom of children to play will be taken, (b) early childhood development is to socialize by doing interesting activities, (c) the application of literacy is assumed only as one effort to fulfill the desire of one party in this case parents Wants his son to quickly master read literature count. Two respondents agreed with the implementation of literacy reading program in early childhood if the child showed a high interest in reading literature.

Of the six respondents of kindergarten teachers found three respondents did not agree with the implementation of literacy reading program in early childhood because the AUD is not ready burdened with literacy and child counting material is still dominated by the desire to play. However, three respondents said they agree with the implementation of literacy reading program in PAUD on the grounds that early childhood is the beginning / period to introduce literacy before the children enter the primary school education level, so that the independence of students trained from an early age. But in the implementation should still be assisted by using the media or an interesting method.

Of the six respondents, parents of kindergarten students found one respondent who did not agree with the implementation of literacy reading program in PAUD because PAUD level is the period of play and socialize, it would be nice if filled with activities that sharpen children's social. But on the other hand, there are five respondents who agree with the implementation of literacy reading program in early childhood, with rational: (a) in early childhood education is considered the early stage of reading and writing read and brain development of early childhood is considered to be able to receive well if $(B)$ as the first step in preparing children to enter elementary school education, and (c) in the implementation of literacy program, must still pay attention to child development and how to introduce literacy in early childhood is also assisted by the tools View or varied media.

So it can be concluded that from 18 respondents kindergarten group, $44.44 \%$ of respondents do not agree with the implementation of literacy reading program in PAUD remember: (a) early childhood is the time to play child, know the environment, if the program is implemented then the freedom of children to play will be taken, (b) Early childhood is to socialize by doing interesting activities, (c) the application of literacy is assumed to be only one attempt to meet the desire of one party in this case the parents of students who want their children quickly master read and write count.

As many as $55.56 \%$ of respondents agree with the implementation of literacy reading program in PAUD with rational: (a) early childhood education is the early stage of knowing read and calculate the brain count of early childhood is considered to be able to receive well if introduced with read write arithmetic, (b) as a first step to prepare children to enter primary school education.

Based on the elaboration of the conclusions of each of the above groups, the following general conclusions can be drawn. Of the 48 respondents, $58.33 \%$ of respondents agreed with the implementation of literacy reading program in PAUD educational 
institutions, while $41.67 \%$ of respondents did not agree with the implementation of literacy reading program in early childhood. Most of the respondents agreed with the implementation of literacy reading program in early childhood due to the following matters: (a) the 2013 curriculum has been enacted in elementary school, thus indirectly demanding the AUD child to know the literacy program although it is still an introduction, (b) ) Planting the basic concept of literacy counting is important before the learner enters the elementary school level, so that children will more easily understand the literacy materials taught in elementary school. Letters and numbers are the symbols that exist around the child, so children need to recognize these symbols early on early childhood. Cognitively, early childhood has the ability to understand the symbols that exist, so if applied literacy programs calculate with the right method, then the child will be able to understand letters and numbers well.

The disagreement shown by other respondents is due to: (a) the reality in the field shows that there are still many PAUD institutions that have not been able to provide the service of literacy reading program in accordance with the characteristics of PAUD students. Most PAUD institutions implement literacy programs based on the demands of parents who expect their children to be admitted to a favorite elementary school and as a result the rights of children to play will be deprived and there is a deep fear in children who are not good at literacy, (b) early childhood Is the child's early years of learning about the school world and the surrounding environment, so it will be a tough task if AUD is taught reading material, (c) PAUD still focuses on stimulating sensory, motor, and cognitive nerves. This means that AUD does not have complete readiness when burdened with academic burden, and it is feared students will quickly experience saturation while in elementary school level. Differences in opinion about whether or not learning literacy reading count, especially reading due to different understandings about the concept of learning to read in kindergarten. Essentially reading reading in kindergarten is readiness that emphasizes skills that include vocabulary, sharpening or matching words, pictures, letters, or words visually, or mentioning the names of the letters and reading the word (Basuki, 2013).

With regard to the implementation of the test in the admission of new students in primary school, from 48 respondents $43.75 \%$ agreed and $56.25 \%$ stated disagree. Groups that agree and disagree with the implementation of new admissions tests in elementary school have several reasons or arguments. This shows that the implementation of new admissions tests in elementary schools still raises the pros and cons. Although the pro-enrollment group in the new primary school admission rate is greater, the counter group is also a significant percentage. The two groups' arguments need to be analyzed and examined more deeply by various stakeholders, including government officials in education, education practitioners, education specialists, kindergartens, elementary schools, and parents. Analysis and review can be carried out in the form of focus group discussions, seminars, workshops, or more in-depth research. Through deep analysis and study it is expected to find similarities of perception and equality of steps in the development of learning in early childhood and its continuation in elementary school learning. This includes the transition from early childhood to primary school that includes the preparation of the transition curriculum of both levels of education, entrance to primary school, learning strategies, and so forth.

\section{Conclusion}

Based on the description on the results of research and discussion, can be drawn five conclusions as follows.

(1) Implementation of literacy program in Early Childhood Education: from 48 respondents, $58.33 \%$ of respondents agreed with the implementation of literacy reading program in PAUD educational institutions, while $41.67 \%$ of respondents did not agree with the implementation of literacy program in the count PAUD. Each group has its own arguments against their opinions.

(2) Several ways to implement literacy programs in Childhood Education: (a) methods that can be implemented in implementing literacy programs are using play and recognition approaches with self-sourced material, (b) methods that can Used to introduce letters by assembling their own names, introducing the concept of numbers through objects, (c) fun methods for students (not robbing the right of play) and following a predetermined curriculum, educators must still take into account individual differences, (d) The application of concrete media in the introduction of simple letters and words, (e) the method of play, the task of the teacher is to create activities that are pleasing and interested by the child, so that without realizing the activities they do actually have introduced literacy, (f) the teacher should only introduce letters And numbers without forcing children to read and write whole sentences, (g) repetitive practice until the child is able to understand the words and sentences is a method that can be done in implementing literacy programs, (h) using objects and symbols around the children to use multimedia and contextual approach in everyday life, and .

(3) Errors occurring in the field with regard to the application of literacy programs in Early Childhood Education are: (a) for institutions that have applied literacy, means taking the right of learners to learn, whereas their interest has not yet been studied, (b) too hasty in introducing numbers and letters to students, (c) kekurangmaksimalan use of media provided natural 
surroundings can actually be used as a medium of learning support reading, writing and counting in early childhood, (d) the demands of parents that their children are taught reading writing and counting as demanded entering elementary school, (e) mismatch between teaching methods applied by educators from pre to the stage of development of students, due to the obsession of parents and the demands of entry to primary school, (f) differences in the basic concepts of reading, writing and counting between early childhood teachers And elementary school became one of the causes of mutual blame between the two institutions, (g) lack of knowledge educators about the relevant method applied in early childhood, (h) kekurangmaksimalan use of media provided natural surroundings can actually be used as a medium of learning support reading, writing and counting in early childhood, (i) force a child to read and write a complete sentence, (j) kekurangmampuan teacher to present the material in an interesting method, fatigue experienced by children because the material provided sometimes requires the child to copy quite a lot, as well as the fear of children will be punished if one task, (k) the introduction of letters that often begins with an introduction to letters capital and pronunciation of consonants is erroneous, (I) nonoptimal given program because of limited facilities and infrastructure, as well as the number of learners who are relatively large $(>20$ students), ( $m$ ) the lack of an active role of parents to participate in monitoring the development of their children, And (n) students are directed to know the numbers and letters that are has injured the early childhood slogan of learning while playing.

(4) Efforts that can be made to prevent and overcome errors that occur in the field regarding the implementation of literacy programs in Early Childhood Education are (a) the socialization of early childhood programs to the community and provide an understanding of the curriculum of early childhood teachers, (b) to monitor (C) parents to exclude children who are still at an early age on non-school or tutoring lessons, (d) early childhood institutions to carry out education in accordance with prevailing rules or regulations, (e) socialize about early childhood to the community and inform Programs taught at PAUD level, (f) improving PAUD teachers' professionalism through workshops or trainings in relation to literacy and intensive coordination between teachers, teachers and government in relation to the application of literate reading relevant to $A U D,(g)$ fosters more intensive relations and coordination Sustainability between parents and educators jointly observe the child's interest in learning to read and write the child's development after the literacy program is given, (h) applying the appropriate method and adapted to the characteristics and stages of the student's development; (i) providing the means and Adequate infrastructure and provide a broad space for the development of children can be used as an effort to prevent the emergence of barriers in the implementation of literacy programs, (j) apply the relevant teaching methods and as a follow-up of the implementation of literacy program, then Continuous coordination with parents, and $(k)$ raising awareness of educators that it is essential to create a conducive learning environment (fun and exciting) for children and the use of varied, innovative, and interesting teaching methods that must be maximized.

(5) The public opinion about the implementation of the test in the admission of new students in elementary school is partly agreed and some disagree. Of 48 respondents $43.75 \%$ agreed and $56.25 \%$ stated disagree. Groups that agree and disagree with the implementation of new admissions tests in elementary school have several reasons or arguments. This shows that the implementation of new admissions tests in elementary schools still raises the pro and contra opinion.

\section{REFERENCES}

[1] Agung, A. A. Gede. 2014. Metodologi Penelitian Pendidikan. Malang: Aditya Media Publishing.

[2] Basuki. 2013. Pengembangan Model Pembelajaran Membaca dengan Pelabelan Objek Sekitar (POS) bagi Murid Taman Kanak-Kanak. Litera, 12 (2): 197-208.

[3] Daniel, M. 2003. Metode Penelitian Sosial Ekonomi. Jakarta: Bumi Aksara.

[4] Danim, S. 2007. Metode Penelitian untuk Ilmu-ilmu Perilaku. Jakara: PT Bumi Aksara.

[5] Fishbein, M. \& Icek Ajezen. 1975. Belief, Attitude, Intension and Behavior. "An Introduction to Theory and Research". London: Addison Wesley.

[6] Hadi, Syamsul. 2011. Pembelajaran Sosial Emosional sebagai Dasar Pendidikan Karakter Anak Usia Dini. Jurnal Teknodik, Volume XV, Nomor 2, Desember 2011, halaman 227-240, Pusat Teknologi Informasi dan Komunikasi Pendidikan, Jakarta.

[7] Musfiroh, T. 2009. Pemerolehan Bahasa Tulis Produktif Anak Kelompok Bermain dan Taman KanakKanak. Humaniora, 21 (3): 259-273.

[8] Natawijaya, Rochman. 1985. Proses Penyusunan Skala Sikap. Bandung: FIP IKIP Bandung.

[9] Peraturan Menteri Pendidikan Nasional Republik Indonesia Nomor 58 Tahun 2009 tentang Standar Pendidikan Anak Usia Dini.

[10] Peraturan Pemerintah Nomor 19 Tahun 2005 tentang Standar Nasional Pendidikan.

[11] Sukiman. 2013. Tinjauan Pedagogis Pembelajaran Calistung di PAUD. Makalah disampaikan dalam 
Seminar Nasional yang Diselenggarakan oleh Jurusan PG PAUD FIP Undiksha di Singaraja.

[12] Saepudin, Asep. 2011. Pembelajaran Sains pada Program Pendidikan Anak Usia Dini. Jurnal Teknodik, Volume XV, Nomor 2, Desember 2011, halaman 213-226, Pusat Teknologi Informasi dan Komunikasi Pendidikan, Jakarta.

[13] Singarimbun, M. 1989. Metode dan Proses Penelitian. Dalam Masri Singarimbun \& Sofian Effendi (Eds.), Metode Penelitian Survai (hlm. 3-14). Jakarta: Lembaga Penelitian, Pendidikan dan Penerangan Ekonomi dan Sosial (LP3ES).

[14] Undang-Undang Republik Indonesia Nomor 20 tahun 2003 tentang Sistem Pendidikan Nasional. Bandung:Fokusmedia.

[15] Warsihna, Jaka. 2016. Meningkatkan Literasi Membaca dan Menulis dengan Teknologi Informasi dan Komunikasi (TIK). Kwangsan Jurnal Teknologi Pendidikan, Vol 4 (2): 67-80. 